Etikonomi

Volume 14 (2), Oktober 2015

P-ISSN: 1412-8969; E-ISSN: 2461-0771

Halaman $241-256$

\title{
FAKTOR-FAKTOR YANG MEMPENGARUHI PROFITABILITAS BANK SYARIAH
}

\author{
Nur Mawaddah \\ Ikatan Mahasiswa Muhammadiyah \\ nurmawaddah_27@yahoo.co.id
}

\begin{abstract}
.
The aims of this study are to analyze the direct effect of financing and net interest margin to return on asset, and indirect effect of financing and net interest margin into return on asset. The independent variables in this study are financing and net interest margin, the dependent variable is return on asset, and intervening variable is non performing financing (NPF). The method that used in this study is path analysis. The result shown that the financing has direct effect to return on asset $2.45 \%$ and net interest margin has direct effect to return on asset $6.45 \%$. Non performing financing has direct effect to return on asset $4.32 \%$. Financing has indirect effect to non performing financing $2.77 \%$. Net interest margin has indirect effect on non performing financing $2.77 \%$.
\end{abstract}

Keywords: profitability; path analysis; Islamic banks

\begin{abstract}
Abstrak.
Penelitian ini bertujuan untuk menganalisis pengaruh langsung Pembiayaan dan Net Interest Margin (NIM) terhadap Return On Asset (ROA), pengaruh tidak langsung Pembiayaan dan Net Interest Margin (NIM) terhadap Return On Asset (ROA). Variabel independen dalam penelitan ini adalah Pembiayaan dan NIM sedangkan variabel dependennya adalah ROA dan variabel interveningnya adalah Non Performing Finance (NPF). Metode analisis yang digunakan untuk menguji hipotesis adalah analisis jalur. Hasil penelitian ini menunjukan bahwa pembiayaan berpengaruh langsung terhadap Return On Asset (ROA) sebesar 2.45\%. Net Interest Margin (NIM) berpengaruh langsung terhadap Return On Asset sebesar 6.45\%. Non Performing Finance (NPF) berpengaruh langsung terhadap Return On Asset (ROA) sebesar 4.32\%. Pembiayaan berpengaruh tidak langsung terhadap Non Performing Finance (NPF) sebesar 2.77\%. Net Interest Margin (NIM) berpengaruh tidak langsung terhadap Non Performing Finance (NPF) sebesar $2.77 \%$.
\end{abstract}

Kata Kunci: profitabilitas; analisis lajur; perbankan syariah

Diterima: 25 Juli 2015; Direvisi: 5 September 2015; Disetujui: 20 September 2015

http://journal.uinjkt.ac.id/index.php/etikonomi 


\section{PENDAHULUAN}

Kegiatan ekonomi suatu negara sangat dipengaruhi oleh peranan perbankan yang ada di negara tersebut. Perbankan memiliki peran yang sangat penting dalam perekonomian suatu negara. Peran perbankan merupakan tolak ukur kemajuan negara. Semakin baik kondisi perbankan suatu negara, semakin baik pula kondisi perekonomian suatu negara.

Bank merupakan salah satu lembaga keuangan yang berfungsi sebagai perantara keuangan yang menyalurkan dana dari pihak yang berkelebihan dana kepada pihak yang kekurangan dana (Ismail, 2010). Dana yang dimiliki oleh bank adalah berasal dari dana bank itu sendiri, dana dari masyarakat dan dana pinjaman. Bank juga dibebani suatu misi dalam perekonomian Indonesia, yaitu meningkatkan taraf hidup rakyat banyak dengan menyalurkan dana kepada masyarakat dalam bentuk kredit agar daya beli atau usaha masyarakat dapat meningkat, sehingga akan meningkatkan pembangunan ekonomi Indonesia.

Perbankan berperan dalam mempermudah proses pengalihan dana dari pihak yang kelebihan dana pada pihak yang membutuhkan dana, untuk melakukan proses tersebut, perbankan menghimpun dana dari masyarakat yang memiliki kelebihan dana dan menyalurkan dana tersebut kembali kepada masyarakat yang membutuhkan dana tersebut untuk kegiatan yang lebih produktif. Peran tersebut membuat perbankan disebut sebagai lembaga perantara keuangan (financial intermediary institusion). Menurut dari segi imbalan maupun jasa atas penggunaan dana, simpanan ataupun pinjamannya, bank dibedakan menjadi dua, yaitu bank konvensional dan bank syariah.

Bank konvensional adalah bank yang dalam aktivitasnya, baik penghimpunan dana maupun dalam rangka penyaluran dananya, memberikan dan mengenakan imbalan berupa bunga atau sejumlah imbalan dalam persentase tertentu dari dana untuk suatu periode tertentu, sedangkan bank Syariah adalah bank yang dalam aktivitasnya, baik penghimpunan dana maupun dalam rangka penyaluran dananya memberikan dan mengenakan imbalan 
mengacu pada hukum Islam, dan dalam kegiatannya tidak membebankan bunga, maupun tidak membayar bunga kepada nasabah. Imbalan yang diterima oleh bank syariah, maupun yang dibayar nasabah tergantung dari akad dan perjanjian antara nasabah dan pihak bank (Ismail, 2010)

Menurut undang-undang Nomor 10 Tahun 1998 tentang perbankan, bank disebut sebagai badan usaha yang menghimpun dana dari masyarakat dalam bentuk simpanan dan menyalurkannya kepada masyarakat dalam bentuk kredit dan atau bentuk-bentuk lainya dalam rangka meningkatkan taraf hidup masyarakat.

Selain kehadiran bank konvensional, masyarakat kita kini juga mempunyai pilihan untuk menginvestasikan dana yang mereka miliki, tentu melalui kehadiran penghimpunan dana pada perbankan syariah. Perbankan syariah merupakan lembaga yang kegiatan usahanya tidak menerapkan sistem bunga seperti bank konvensional lainnya, melainkan dengan sistem bagi hasil.

Perbankan menurut jenis operasionalnya terbagi menjadi dua yaitu meliputi. Bank konvensional adalah bank yang dalam operasionalnya menerapkan metode bunga, karena metode bunga sudah ada terlebih dahulu, menjadi kebiasaan dan telah dipakai secara meluas dibandingkan dengan metode bagi hasil. Bank konvensional pada umumnya beroperasi dengan mengeluarkan produk-produk untuk menyerap dana masyarakat dan menyalurkan dana yang telah dihimpun dengan cara mengeluarkan kredit.

Sedangkan bank syariah adalah bank yang beroperasi sesuai dengan prinsip-prinsip syariah Islam, maksudnya adalah bank yang dalam operasinya mengikuti ketentuan-ketentuan syariah Islam, khususnya yang menyangkut tata cara bermuamalah secara Islam. Kegiatan bank syariah dalam hal penentuan harga produknya sangat berbeda dengan bank konvensional. Penentuan harga bagi bank syariah didasarkan pada kesepakatan antara bank dengan nasabah penyimpan dana sesuai dengan jenis simpanan dan jangka waktunya, yang akan menentukan besar kecilnya porsi bagi hasil yang akan diterima penyimpan. Dalam rangka menjalankan kegiatannya, bank syariah harus berlandaskan pada 
Al-Qur'an dan hadits. Bank syariah mengharamkan penggunaan harga produknya dengan bunga tertentu. Bagi bank syariah, bunga bank adalah riba.

Perbankan memiliki peran yang strategis dalam menunjang berjalannya roda perekonomian dan pembangunan nasional, mengingat fungsinya sebagai lembaga intermediasi. Perbankan syariah di Indonesia secara yuridis mulai diatur dalam undang-undang No. 7 Tahun 1992 tentang perbankan. Hal tersebut dapat dijadikan sebagai sarana dalam mempromosikan dan mengembangkan perbankan berdasarkan prinsip syariah. Namun dengan berbagai kekurangan dan kelemahan mengenai pengaturan bank syariah dalam UU tersebut, pada tahun 1998 disahkanlah UU No. 10 Tahun 1998 tentang perubahan atas UU No. 7 Tahun 1992 tentang perbankan.

Keberadaan perbankan syariah di Indonesia merupakan refleksi dari kebutuhan atas sistem perbankan alternatif yang lebih dapat memberikan kontribusi positif untuk meningkatkan stabilitas sistem perbankan nasional. Tujuan perbankan syariah adalah menunjang pelaksanaan pembangunan nasional, seperti melakukan fungsi untuk mendukung sektor riil melalui pembiayaan sesuai prinsip syariah yang mendukung pelaksanaan pembangunan nasional dalam rangka pemerataan kesejahteraan rakyat.

Bank syariah telah membuktikan sebagai lembaga keuangan yang dapat bertahan ditengah krisis moneter pada tahun 1997. Pada tahun 2008 ketika terjadi krisis di Amerika, ternyata Indonesia sedang mengembangkan ekonomi syariah tidak terkena dampak yang signifikan dari krisis tersebut. Itu terlihat dari penyaluran pembiayaan oleh perbankan syariah per Februari 2009 secara konsisten terus mengalami peningkatan dengan pertumbuhan sebesar 33,3\% pada Februari 2008 menjadi 47,3\% pada Februari 2009.

Bank sebagai lembaga keuangan mempunyai usaha pokok yaitu menghimpun dana secara sementara sebagai lembaga keuangan, dan kemudian mengalokasikan dana tersebut ke masyarakat yang membutuhkannya untuk jangka waktu yang telah ditentukan. Dalam perbankan syariah untuk penyaluran dananya kita kenal dengan istilah pembiayaan. Penilaian kinerja 
merupakan hal yang esensi bagi sebuah organisasi haruslah mencerminkan peningkatan dari satu priode ke priode berikutnya.

Eksistensi perbankan syariah di Indonesia saat ini semakin meningkat sejak adanya UU No. 21 Tahun 2008 tentang perbankan syariah yang memberikan landasan operasi yang lebih jelas bagi bank syariah. Perkembangan perbankan syariah di Indonesia ini terlihat dari jumlah bank umum syariah yang sekarang telah mencapai 11 bank, unit usaha syariah sebanyak 24 bank, dan 156 bank pembiayaan rakyat syariah.

Kinerja sebuah perusahaan lebih banyak di ukur berdasarkan rasiorasio keuangan selama satu periode tertentu. Pengukuran rasio keuangan ini sangatlah bergantung pada metode atau perlakuan akuntansi yang digunakan dalam menyusun laporan keuangan perusahaan. Laporan keuangan bank menunjukkan kondisi keuangan bank secara keseluruhan. Laporan ini juga menunjukkan kinerja manajemen bank selama satu priode. Keuntungan dengan membaca laporan ini pihak manajemen dapat memperbaiki kelemahan yang ada serta mempertahankan kekuatan yang dimilikinya.

Rasio merupakan alat yang dinyatakan dalam artian relatif maupun absolut untuk menjelaskan hubungan tertentu antara faktor satu dengan lainnya dari suatu laporan finansial. Rasio-rasio finansial umumnya diklasifikasikan menjadi 4 macam yaitu rasio likuiditas, rasio solvabilitas, rasio aktiva, dan rasio profitabilitas. Rasio profitabilitas adalah rasio yang digunakan untuk mengukur kemampuan perusahaan menghasilkan laba selama satu periode akuntansi dan mengukur tingkat efisiensi operasional dalam menggunakan aktiva yang dimilikinya. Indikator yang bisa digunakan untuk mengukur kinerja profitabilitas bank salah satunya adalah ROA (Return On Asset) yaitu adalah rasio profitabilitas yang menunjukan perbandingan antara laba (sebelum pajak) dengan total aset bank, rasio ini menunjukkan tingkat efisiensi pengelolaan aset yang dilakukan oleh bank yang bersangkutan.

Profitabilitas adalah rasio yang digunakan untuk melihat kemampuan perusahaan dalam menghasilkan laba (Hanafi \& Halim, 2000). Setiap perusahaan akan berusaha untuk meningkatkan kinerja perusahaannya dalam 
rangka untuk meningkatkan produktivitas dan laba perusahaan. Kinerja keuangan bank merupakan suatu ukuran yang menggambarkan kondisi keuangan suatu bank. Bagi nasabah, sebelum mendepositkan dananya di suatu bank mereka akan melihat terlebih dahulu kinerja keuangan bank tersebut melalui laporan keuangan berupa neraca dan laba rugi. Salah satu indikator yang digunakan untuk melihat kinerja keuangan dari sisi profitabilitas adalah Return on Assets (ROA). Bank Indonesia menilai kondisi profitabilitas perbankan di Indonesia didasarkan pada dua indikator yaitu Return on Asset (ROA) atau tingkat pengembalian asset dan Rasio Biaya Operasional terhadap Pendapatan Operasional (BOPO). Semakin besar Return on Assets

(ROA) suatu bank maka semakin besar pula tingkat keuntungan yang dicapai bank tersebut, dan semakin baik pula posisi bank tersebut dari segi penggunaan aset. Berdasarkan Surat Edaran Bank Indonesia Nomor 12/11/DPNP tanggal 31 Maret 2010 tentang Sistem Penilaian Tingkat Kesehatan Bank Umum berdasarkan prinsip Syariah, Return on Assets (ROA) didapat dengan cara membagi laba sebelum pajak dengan rata-rata total aset dalam suatu periode (Bank Indonesia). Secara spesifik, (rivai, 2007) menjelaskan bahwa profitabilitas bank dapat dipengaruhi oleh dua faktor, yaitu faktor eksternal dan faktor internal. Faktor eksternal merupakan faktor yang berasal dari luar bank, misalnya kondisi perekonomian, kondisi perkembangan pasar uang dan pasar modal, kebijakan pemerintah, dan peraturan Bank Indonesia. Sedangkan faktor internal merupakan faktor yang bersumber dari bank itu sendiri, misalnya produk bank, kebijakan suku bunga atau bagi hasil di bank syariah, kualitas layanan, dan reputasi bank.

Haron (1996, 2004) dalam penelitiannya menyebutkan bahwa faktor-faktor yang mempengaruhi profitabilitas bank syariah hampir sama dengan faktor-faktor yang mempengaruhi bank konvensional. Di mana pada pada penelitian sebelumnya ia menjelaskan bahwa profitabilitas bank konvensional ditentukan oleh dua faktor, yaitu faktor internal dan faktor eksternal. Faktor internal merupakan faktor-faktor yang berasal dari 
manajamen bank itu sendiri, seperti penghimpinan dana, manajemen modal, manajemen likuiditas dan manajemen biaya. Sedangkan faktor eksternal adalah faktor-faktor yang berasal dari luar bank dan tidak dapat dikendalikan oleh bank, seperti persaingan, regulasi, konsentrasi, pangsa pasar, kepemilikan, kelangkaan modal, jumlah uang beredar, inflasi, skala ekonomi, besaran bank, dan lain-lain.

\section{METODE}

Penelitian ini menggunakan jenis data kuantitatif. Data kuantitatif merupakan data yang didominasi oleh angka. Data ini mempresentasikan satu ukuran kuantitatif objek peneliti dalam suatu ukuran tertentu. Pengumpulan data yang dilakukan adalah dengan menggunakan data sekunder laporan keuangan triwulan Bank Syariah Mandiri. Teknik analisis yang dipergunakan dalam penelitian ini adalah teknik analisis jalur (Path Analysis). Sebelum di uji menggunakan path analysis terlebih dahulu di uji menggunakan uji statistik normalitas.

Analisis jalur merupakan teknik statistik yang digunakan untuk menguji hubungan kausal antara dua atau lebih variabel. Teknik ini pertama kali dikembangkan oleh seorang ahli genetika bernama Sewall Wright pada tahun 1920. Analisis jalur (path analysis) untuk pertama kali diperkenalkan oleh biolog bernama Sewall Wright (1921) dan selanjutnya dikembangkan ke dalam ilmu-ilmu sosial oleh sosiolog O.D. Duncan (1960).

Aspek teoritis analisis jalur model Sewall Wright tidak ada hall baru, analisis regresi klasik dapat digunakan sehingga asumsi-asumsi regresi klasik terikat pada analisis jalur tersebut. Tujuan analisis jalur adalah apakah model yang diusulkan cocok tidak dengan data, yaitu dengan cara membandingkan matriks korelasi teoritis dengan matriks korelasi empiris. Jika kedua matriks relatif sama, maka model dikatakan "cocok" atau fit. Secara formal pengujian ini menggunakan koefisien multipel determinasi umum (Pedhazur, 1982).

Metode yang digunakan adalah analisis jalur (path analysis). Menurut Kothari teknik analisis jalur didasarkan pada analisis multiregresi dengan tambahan asumsi relasi kausal antara variabel bebas (independent) dan variabel 
terikat (dependent). Jadi model path analysis digunakan untuk menganalisis pola hubungan antara variabel dengan tujuan untuk mengetahui pengaruh langsung maupun tidak langsung variabel bebas terhadap variabel terikat.

Manfaat dari model analisis jalur adalah untuk menjelaskan fenomena yang diteliti, memprediksi nilai variabel terikat $(\mathrm{Y})$ berdasarkan nilai variabel bebas $(\mathrm{X})$, faktor determinan yaitu penentuan variabel bebas $(\mathrm{X})$ mana yang berpengaruh dominan terhadap variabel terikat $(\mathrm{Y})$, juga dapat digunakan untuk menelusuri mekanisme (jalur-jalur) pengaruh variabel bebas $(\mathrm{X})$ terhadap variabel terikat $(\mathrm{Y})$, dan pengujian model menggunakan metode trimming. Prinsip-prinsip dasar yang sebaiknya dipenuhi dalam analisis jalur diantaranyaialah (Kuncoro, 2008):

1. Hubungan antar variabel adalah bersifat adaptif dan bersifat normal.

2. Hanya sistem aliran kausal ke satu arah artinya tidak ada arah kausalitas yang berbalik.

3. Variabel terikat (endogen) minimal dalam skala ukur interval dan rasio.

4. Menggunakan sampel probability sampling yaitu teknik pengambilan sampel untuk memberikan peluang yang sama pada setiap anggota populasi untuk dipilih menjadi anggota sampel

5. Observed variable diukur tanpa kesalahan (instrumen pengukuran validitas dan reliabilitas) artinya variabel yang diteliti dapat diobservasi secara langsung.

6. Model yang dianalisis dispesifikasikan (diidentifikasi) dengan benar berdasarkan teori-teori dan konsep-konsep yang relevan artinya model teori yang dikaji atau diuji dibangun berdasarkan kerangka teoritis tertentu yang mampu menjelaskan hubungan kausalitas antar variabel yang diteliti.

Model analisis jalur berbeda dengan model regresi. Perbedaan tersebut terletak pada pola hubungan yang ingin diungkapkan. Model regresi digunakan untuk meramalkan atau menduga nilai sebuah variabel respon $\mathrm{Y}$ atas dasar nilai tertentu beberapa variabel prediktor X1; X2, ..., Xk, atau pola hubungan yang 
mengisyaratkan besarnya pengaruh variabel penyebab X1; X2, ..., Xk, terhadap sebuah variabel akibat $\mathrm{Y}$, baik pengaruh yang langsung secara individual maupun secara bersamaan. Telaah statistika menyatakan bahwa untuk peramalan/pendugaan nilai $\mathrm{Y}$ atas dasar nilai-nilai X1; X2, .., Xk, pola hubungan yang sesuai adalah pola hubungan yang mengikuti model regresi, sedangkan untuk mengetahui hubungan sebab akibat, pola yang tepat adalah model struktural. Secara matematik, analisis jalur mengikuti pola model struktural (Riduwan \& Kuncoro, 2008). Model struktural yaitu apabila setiap variabel terikat/endogen ( $\mathrm{Y}$ ) keadaannya ditentukan oleh seperangkat variabel bebas/eksogen (X). Berikut beberapa perbedaan model regresi dan model analisis jalur.

\section{Gambar 1.1}

Model Path Analysis

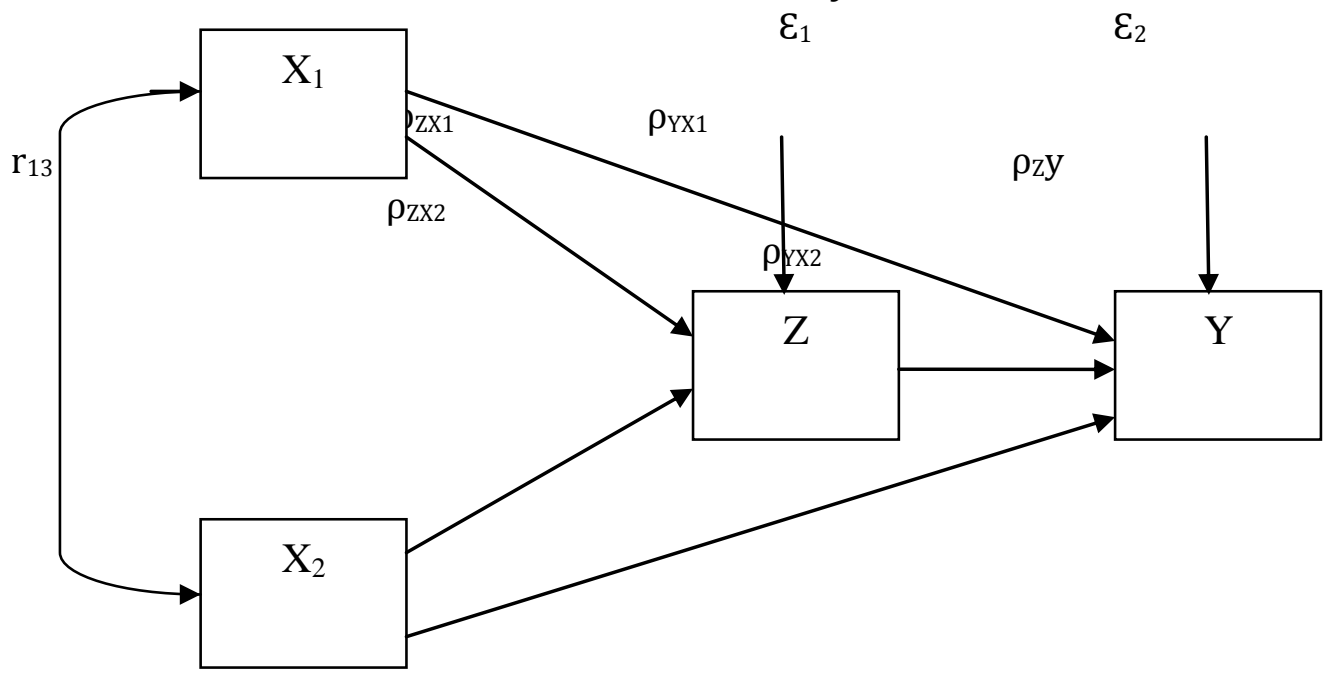

Persamaan matematis yang diajukan pada penelitian ini adalah:

$$
\begin{aligned}
& Z=\rho_{\mathrm{ZX} 1} \mathrm{X}_{1}+\rho_{\mathrm{ZX} 2} \mathrm{X}_{2}+\rho_{\mathrm{ZY}} \mathrm{Y}+\varepsilon_{1} \\
& \mathrm{Y}=\rho_{\mathrm{YX} 1} \mathrm{X}_{1}+\rho_{\mathrm{YX} 2} \mathrm{X}_{2}+\varepsilon_{2}
\end{aligned}
$$

\section{Dimana:}

$\mathrm{Y}=$ Return On Asset (ROA)

$\mathrm{X}_{1}=$ Pembiayaan

$\mathrm{X}_{2}=$ Net Interest Margin (NIM)

$\mathrm{Z}=$ Non Performing Finance (NPF)

$\varepsilon=$ Error 


\section{PEMBAHASAN}

\section{Perhitungan Koefisien Jalur pada Sub-Struktur 1}

Model struktur yang ditampilkan pada Gambar 1.1 diatas terdiri dari dua sub-struktur, yaitu Sub-Struktur 1 dan Sub-Struktur 2. Hubungan kausal antar variabel pada Sub-Struktur 1, yang ditampilkan pada Gambar 1.2 dibawah, terdiri dari satu variabel endogen yaitu $\mathrm{Z}$ dan dua variabel eksogen yaitu $\mathrm{X}_{1}$ dan $\mathrm{X}_{2}$.

\section{Gambar 1.2}

\section{Hubungan kausal pada Sub-Struktur 1}

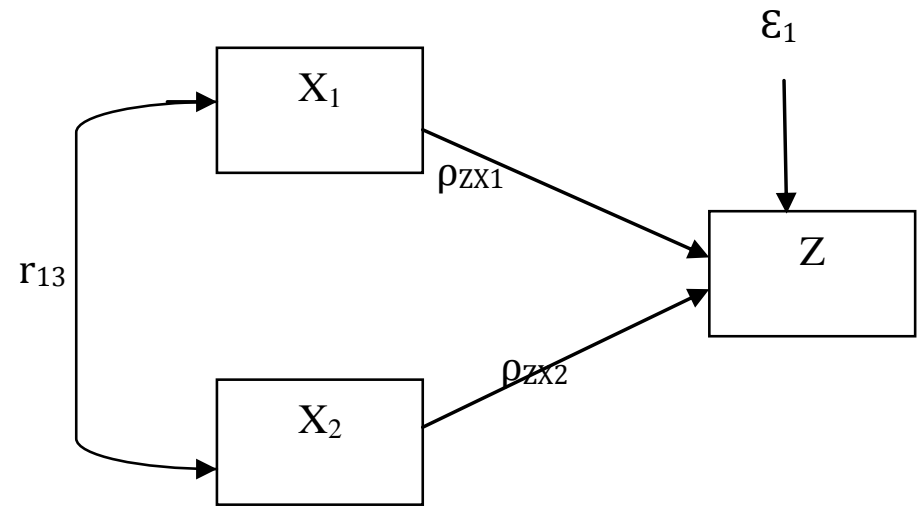

Berdasarkan hasil pengolahan data menggunakan SPSS analisis jalur substruktur 1 (X1, X2, dan Z) yang nampak pada tabel Coefficients sub-struktur 1, masing-masing diperoleh nilai:

a) $\rho Z X 1=$ Beta $=-0,072[\mathrm{t}=-0,383$ dan probabilitas $(\operatorname{sig})=0,705]$

b) $\rho Z X 2=$ Beta $=-0,156[\mathrm{t}=-0,826$ dan probabilitas $(\operatorname{sig})=0,415]$

Hasil analisis membuktikan bahwa semua koefisien jalur tidak signifikan. Berdasarkan hasil analisis pada tabel diperoleh nilai koefisien jalur X1 terhadap Z sebesar $\rho Z X 1=-0,072$ dan X2 terhadap Z sebesar $\rho Z X 2=-0,156$. Sedangkan koefisien determinasi kontribusi X1 dan X2, terhadap Z adalah Rsquare $=0,035$, yang berarti bahwa 3,5\%. Besar koefisien residu $\rho Z \mathcal{E} 1=(1-0,035)=0,965$ merupakan pengaruh variabel lain diluar X1 dan X2. Dengan demikian persamaan struktural untuk Sub-Struktur 1 adalah $Z=-0,072 X 1+(-$ 
0,156)X2+ 0,965 dan diagram jalurnya seperti pada Gabar 1.3 sebagai berikut:

Gambar 1.3

Hubungan kausal pada Sub-Struktur 1

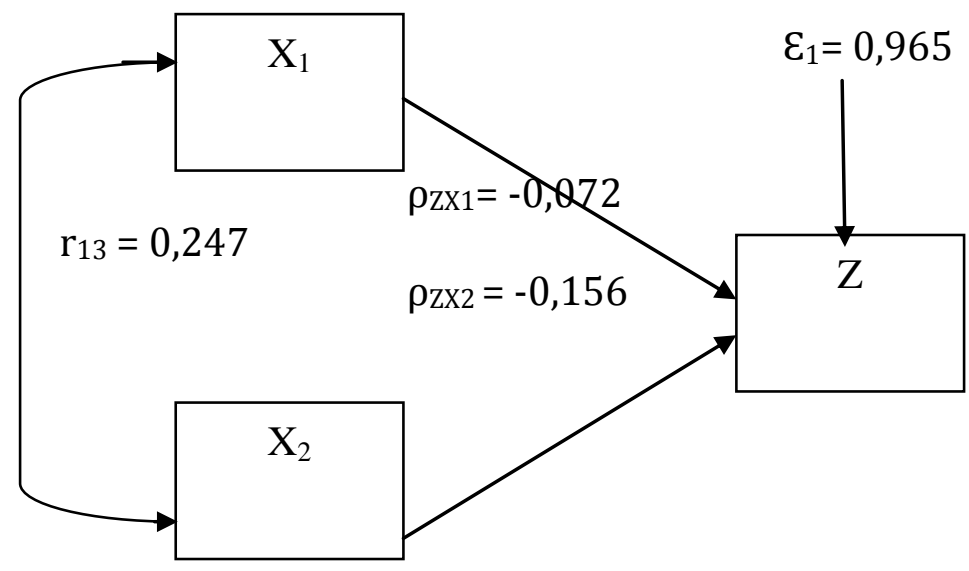

\section{Perhitungan Koefisien Jalur pada Sub-Struktur 2}

Model struktur yang ditampilkan pada Gambar 1.1 diatas terdiri dari dua sub-struktur, yaitu Sub-Struktur 1 dan Sub-Struktur 2. Hubungan kausal antar variabel pada Sub-Struktur 2, yang ditampilkan pada Gambar 1.4 dibawah, terdiri dari satu variabel endogen yaitu Y dan tiga variabel eksogen yaitu X1 dan X2 dan Z.

Berdasarkan hasil pengolahan data menggunakan SPSS analisis jalur sub-struktur 2 (X1, X2, Z dan Y) yang nampak pada tabel Coefficients sub-struktur 2, masing-masing diperoleh nilai :

a) $\rho \mathrm{YX} 1=\mathrm{Beta}=-0,495[\mathrm{t}=-4,366$ dan probabilitas ( $\operatorname{sig})=0,000]$

b) $\rho Y X 2=$ Beta $=0,254[\mathrm{t}=2,221$ dan probabilitas $(\operatorname{sig})=0,035]$

c) $\rho Z Y=$ Beta $=-0,657[\mathrm{t}=-5.892$ dan probabilitas $(\operatorname{sig})=0,000]$ 


\section{Gambar 1.4 \\ Hubungan kausal pada Sub-Struktur 2}

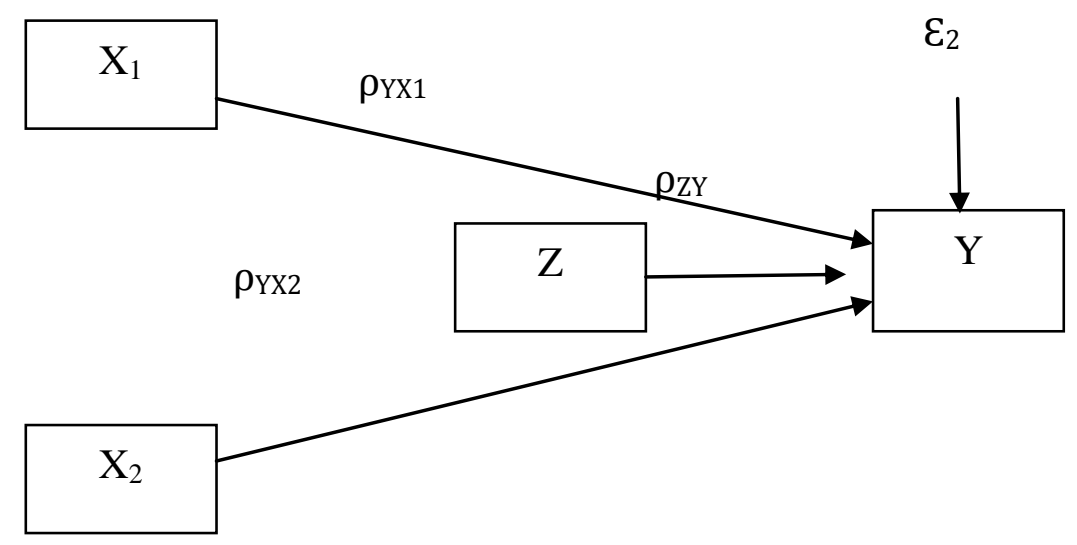

Hasil analisis membuktikan bahwa semua koefisien jalur signifikan. Berdasarkan hasil analisis pada tabel diperoleh nilai koefisien jalur X1 terhadap $\mathrm{Y}$ sebesar $=-0,495, \mathrm{X} 2$ terhadap $\mathrm{Y}$ sebesar $=0,254$ dan $\mathrm{Z}$ terhadap $\mathrm{Y}=-0,657$. Sedangkan koefisien determinasi kontribusi X1, X2, Z terhadap Y adalah Rsquare $=0,664$, yang berarti bahwa 66,4\%. Besar koefisien residu untuk $\rho Y$ $\varepsilon 2=(1-0,664)=0,336$, merupakan pengaruh variabel lain di luar X1, X2, dan Z Dengan demikian persamaan struktural untuk Sub-Struktur 2 adalah $\mathrm{Y}=$ $0,495 \mathrm{X} 1+0,254 \mathrm{X} 2+(-0,657)+0,336$ dan diagram jalurnya seperti pada Gabar 1.5 sebagai berikut:

\section{Gambar 1.5}

Hubungan kausal pada Sub-Struktur 2

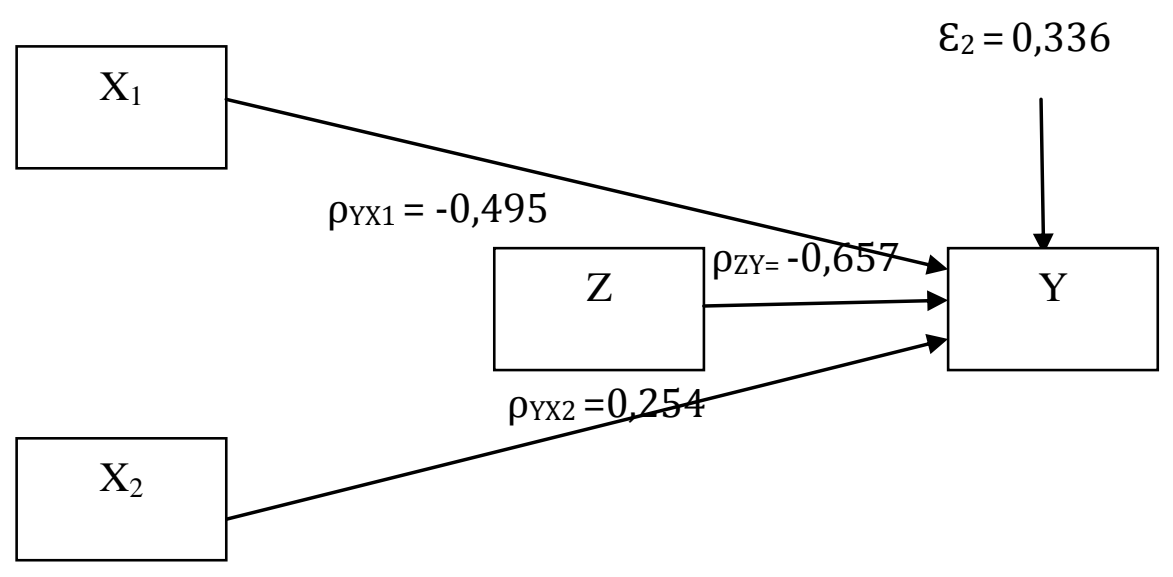


Berdasarkan hasil dari sub-struktur 1 dan sub-struktur 2, maka dapat digambarkan secara keseluruhan yang menggambarkan hubungan antarvariabel $\mathrm{X}_{1}, \mathrm{X}_{2}$, Z terhadap $\mathrm{Y}$ sebagaiberikut:

\section{Gambar 1.6}

\section{Hubungan kausal pada Sub-Struktur 2}

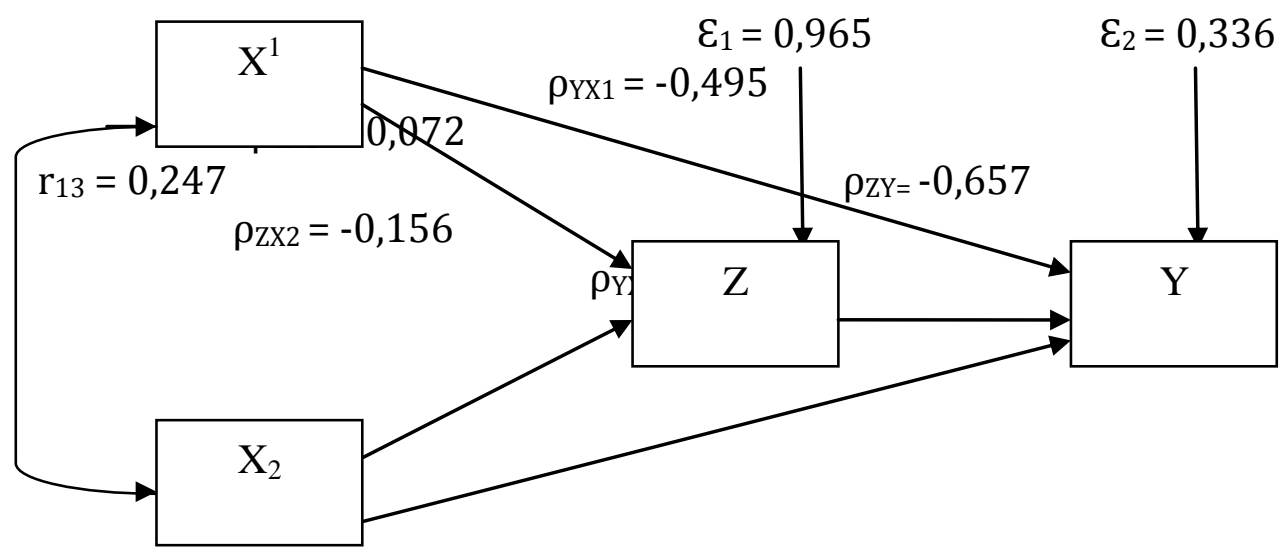

Hasil dari koefisien jalur sub-struktur 1 dan sub-struktur 2 berubah menjadi persamaan struktur, sebagai berikut:

$$
\begin{aligned}
& Z=\rho Z X 1 X 1+\rho Z X 2 X 2+\rho Z \varepsilon 1 \text { dan } R 2 \\
& Z=-0,072 X 1+(-0,156) X 2++0,965 \varepsilon 1 \text { dan } R 2=0,035 \\
& Y=\rho Y X 1 X 1+\rho Y X 2 X 2+\rho Z Y Y+\rho Y \varepsilon 2 \text { dan } R 2 \\
& Y=-0,495 X 1+0,254 X 2+(-0,657) Y+0,336 \varepsilon 2 \text { dan } R 2=0,664
\end{aligned}
$$

\section{SIMPULAN}

Penelitian ini bertujuan untuk mengetahui dan menganalisis pengaruh variabel independen (Pembiayaan, Net Interest Margin (NIM)) terhadap variabel dependen (Return On Asset (ROA)) dengan variabel intervening (Non Performing Finance (NPF)) pada Bank Syariah Mandiri. Di mana teknik pengumpulan data pada penelitian ini menggunakan data sekunder dari laporan publikasi triwulan yang didapat dari situs resmi Bank Syariah Mandiri selama tahun 2007-2014, maka dapat ditarik kesimpulan sebagai berikut:

Hasil analisis data menunjukan bahwa Pembiayaan berpengaruh langsung terhadap Return On Asset (ROA) sebesar 2,45\%. Net Interest Margin 
(NIM) berpengaruh langsung terhadap Return On Asset sebesar 6,45\%. Non Performing Finance (NPF) berpengaruh langsung terhadap Return On Asset (ROA) sebesar 4,32\%. Pembiayaan berpengaruh tidak langsung terhadap Non Performing Finance (NPF) sebesar 2,77\%. Net Interest Margin (NIM) berpengaruh tidak langsung terhadap Non Performing Finance (NPF) sebesar 2,77\%. Berdasarkan kesimpulan tersebut diatas, dapat dijelaskan bahwa variasi ROA paling dominan dipengaruhi secara langsung oleh Pembiayaan dan NIM. Sedangkan Pembiayaan dan NIM tidak berpengaruh langsung oleh NPF.

\section{PUSTAKA ACUAN}

Artwienda, MS Nur \& Prasetiono. 2012. Analisis Pengaruh Capital Adequacy Ratio, Non Performing Loan, BOPO, Net Interest Margin, dan Loan To Deposit Ratio Terhadap Perubahan Laba. Jurnal Bisnis dan Ekonomi. 27 November 2012, hlm. 1-15.

Dendawijaya, L. 2009. Manajemen Perbankan. Bogor: Ghalia Indonesia.

Faisal, S. 2005. Format-format Penelitian Sosial. Jakarta: PT Rajagrafindo Persada.

Ghufron, S. 2005. Konsep dan Implementasi Bank Syariah. Jakarta: Renaisan.

Hanafi, M.M. \& A. Halim. 2007. Analisis Laporan Keuangan. Yogyakarta: UUP STIM YKPI.

Harahap, S.S. 2002. Analisis Kritis Atas Laporan Keuangan. Jakarta: PT Raja Grafindo Persada.

Haryono, S. 2009 Analisis Keuangan Perbankan Syariah. Yogyakarta: Pustaka Sayid Sabiq.

Hasibuan, M. P. 2006. Dasar-Dasar Perbankan. Jakarta: PT Bumi Aksara.

Idrus, M. 2009. Metode Penelitian Ilmu Sosial: Pendekatan Kualitatif dan Kuantitatif. Jakarta: Erlangga.

Ihsan, D.N. 2013. Analisis Laporan Keuangan Perbankan Syariah. Jakarta, UIN Press. 
Iska, S. 2012. Sistem Perbankan Syariah Di Indonesia Dalam Perspektif Fikih Ekonomi. Yogyakarta: Fajar Media Press.

Ismail. 2011. Perbankan Syariah. Jakarta: Kencana.

Kadir. 2010. Statistika Untuk Penelitian Ilmu-Ilmu Sosial (Dilengkapi Dengan Output Program SPSS). Jakarta: PT Rosemata Sampurna.

Kasmir. 2002. Bank \& Lembaga Keuangan Lainnya. Jakarta: PT Raja Grafindo Persada.

Kasmir. 2006. Manajemen Perbankan. Jakarta: PT Raja Grafindo Persada.

Kasmir. 2008. Dasar-Dasar Prbankan. Jakarta: PT Raja Grafindo Persada.

Kontur, R. 2007. Metode Penelitian: untuk Penulisan Skripsi dan Tesis. Jakarta: PPM.

Laksmana, Y. 2009. Panduan Praktis Account Officer Bank Syariah Memahami Praktik Proses Pembiayaan di Bank Syariah. Jakarta: Kompas Gramedia.

Muhammad. 2005. Manajemen Bank Syariah. Yogyakarta: UPP AMPYKPN.

Najmudin. 2011. Manajemen Keuangan dan Aktualisasi Syar'iyyah Modern. Yogyakarta: C.V Andi Offset.

Perwataatmadja, K.A. \& H. Tanjung. 2011. Bank Syariah Teori, Praktik, dan Peranannya. Jakarta: PT Senayan Abadi.

Purwanto. 2012. Metodologi Penelitian Kuantitatif: untuk Psikologi dan Pendidikan. Yogyakarta: Pustaka Pelajar.

Riduan \& E.A. Kuncoro. 2014. Cara Menggunakan dan Memakai Path Analysis (Analisis Jalur). Bandung: Alfabeta.

Riyadi, S. 2006. Banking Assets and Liability Management. Jakarta: Lembaga Penerbit Fakultas Ekonomi Universitas Indonesia.

Rivai, Veitzal, Dkk. 2007. Bank and Financial Institution Manajement. Jakarta: PT Raja Grafindo Persada.

Rivai, Veithzal dan Arviyan Arifin 2010. Islamic Banking Sebuah Teori, Konsep, dan Aplikasi. Jakarta: Bumi Aksara.

Riyadi, S. 2006. Banking Assets and Liability Management. Jakarta: Lembaga Penerbit Fakultas Ekonomi Universitas Indonesia. 
Sandjojo, N. 2011. Metode Analisis Jalur (Path Analysis) dan Aplikasinya. Jakarta: Pustaka Sinar Harapan.

Sulhan, M \& E. siswanto. 2008. Manajemen Bank Konvensional dan Syariah. Malang: UIN Malang Press.

Suwiknyo, D. 2010. Analisis Laporan Keuangan Perbankan Syariah. Yogyakarta.

Wiyono, S. \& T. Maulamin. 2012. Memahami Akuntansi Syariah di Indonesia. Jakarta: Mitra Wahana Media.

Yusuf, M. \& Wiroso. 2011. Bisnis Syariah. Jakarta: Mitra Wacana Media. 